\title{
GAMBARAN PENULISAN TERMINOLOGI MEDIS PADA CM 1 PASIEN RAWAT INAP DAN LEMBAR POLIKLINIK PASIEN RAWAT JALAN DI RUMAH SAKIT UMUM UMMI BENGKULU
}

\author{
Djusmalinar' ${ }^{1}$, Ulfatun Ni'mah Al Mubarokah ${ }^{2}$ \\ ${ }^{1,2}$ Prodi D3 Rekam Medis dan Informasi Kesehatan Akademi Kesehatan Sapta Bakti Bengkulu \\ djusmallinar@gmail.com
}

\begin{abstract}
Abstrak
Terminologi medis merupakan ilmu peristilahan medis sebagai sarana komunikasi antar tenaga kesehatan. Dokter yang merawat pasien mempunyai tugas dan tanggungjawab atas penegakan dan penulisan diagnosis sesuai dengan ICD-10. Diagnosis yang ditulis dalam rekam medis harus lengkap, tepat dan jelas sesuai dengan terminologi medis dan arahan yang ada pada buku ICD-10. Tujuan penelitian ini adalah untuk mengetahui gambaran penulisan terminologi medis pada CM 1 pasien rawat inap dan lembar poliklinik pasien rawat jalan di Rumah Sakit Umum Ummi Bengkulu. Jenis penelitian yang digunakan pada penelitian ini adalah deskriptif kuantitatif dengan desain cross-sectional, populasi dalam penelitian ini adalah 1.863 berkas rekam medis rawat inap dan 3.725 berkas rekam medis rawat jalan pada bulan januari-maret 2016, dengan sampel 329 berkas rekam medis rawat inap dan 361 berkas rekam medis rawat jalan dengan teknik pengambilan sampel Systematic Random Sampling. Menggunakan data sekunder, diolah secara univariat. Penelitian ini dilaksanakan di Rumah Sakit Umum Ummi Bengkulu. Hasil analisa univariat, dari 1.863 berkas rekam medis rawat inap, 85 (47\%) penulisan terminologi medis menggunakan istilah yang sesuai dengan ICD-10, 97 (53\%) yang tidak sesuai dengan ICD-10. 50 (34\%) penulisan terminologi medis menggunakan singkatan yang sesuai dengan ICD-10, 97 (66\%) yang tidak sesuai dengan ICD-10. 3.725 berkas rekam medis rawat jalan, 50 (24\%) penulisan terminologi medis menggunakan istilah yang sesuai dengan ICD-10, 161 (76\%) yang tidak sesuai dengan ICD-10. 45 (30\%) penulisan terminologi medis menggunakan singkatan yang sesuai dengan ICD-10, 105 (70\%) yang tidak sesuai dengan ICD-10. Diharapkan bagi Rumah Sakit Umum Ummi Bengkulu dapat mengadakan sosialisasi, pelatihan, pengawasan dan evaluasi terhadap dokter serta membuat daftar singkatan yang ditetapkan oleh pihak rumah sakit sebagai pedoman tentang penulisan terminologi medis yang sesuai dengan ICD-10, dan meletakkan Standar Operasional Prosedur (SOP) tentang penulisan terminologi medis yang sesuai dengan ICD-10 di masing-masing ruang rawat pasien/ruang kerja dokter.
\end{abstract}

Kata Kunci $\quad$ : Terminologi medis, Rawat Inap, Poliklinik

\section{PENDAHULUAN}

Penyelenggaraan rekam medis telah diatur dalam Permenkes RI Nomor 269/MENKES/PER/III/2008 tentang rekam medis Bab 1 Pasal 1 disebutkan bahwa rekam medis adalah berkas yang berisikan catatan dan dokumen tentang informasi medis yang menyangkut identitas pasien, pemeriksaan, pengobatan, tindakan dan pelayanan lain yang telah diberikan kepada pasien. Dengan adanya informasi medis yang ada di rekam medis, riwayat perjalanan penyakit seorang pasien dapat berkesinambungan sehingga akan membantu dalam pengobatan pasien. Untuk mendapat 
informasi medis yang lengkap dan akurat, maka diperlukan suatu kegiatan pencatatan untuk segala kegiatan yang ada di rumah sakit tersebut. Salah satu kegiatan pencatatan tersebut adalah pencatatan diagnosis yang sesuai dengan terminologi medis.

Pencatatan diagnosis yang sesuai dengan terminologi medis, penting untuk penanganan pasien dan merupakan sumber data epidemiologi dan statistik morbiditas dan mortalitas yang bernilai statistik dalam perawatan kesehatan sehingga penulisan diagnosis haruslah lengkap dan tepat (WHO, 2010). Penulisan diagnosis lebih dari satu istilah medis atau terminologi medis untuk penyakit yang sama, akan menyulitkan dalam pengumpulan dan perolehan informasi morbiditas dan mortalitas yang akurat dan tepat (Hatta, 2013).

Sebagai usaha untuk mengorganisasikan dan menstandarkan bahasa medis, para ahli penyelenggara kesehatan berhasil mengembangkan nomenklatur penyakit, sistem klasifikasi penyakit dan perbendaharaan istilah medis klinis. Nomenklatur yang juga dikenal sebagai terminologi medis, merupakan sistem yang digunakan untuk menata daftar kumpulan medis penyakit, gejala, dan prosedur. Istilah-istilah penyakit atau kondisi gangguan kesehatan yang didaftar dalam nomenklatur harus sesuai dengan istilah yang digunakan di dalam suatu sistem klasifikasi penyakit. Sistem klasifikasi penyakit adalah sistem yang mengelompokkan penyakit-penyakit dan prosedur-prosedur yang sejenis ke dalam satu grup nomor kode penyakit dan tindakan yang sejenis. Sesuai peraturan Depkes, sistem klasifikasi yang harus digunakan sejak tahun 1996 sampai saat ini adalah ICD-10 dari WHO (Hatta, 2013).

Hasil survei Depkes RI (2010) terhadap 15 rumah sakit yang berpartisipasi dalam sistem case mix/INA-CBG's sebagian rumah sakit di indonesia (sekitar 65\%) belum membuat diagnosis yang lengkap dan jelas berdasarkan ICD-10 serta belum tepat pengkodeannya. Apabila diagnosis dan kode yang dicantumkan pada berkas rekam medis tidak tepat, maka akan berdampak pada biaya pelayanan kesehatan. Keakuratan kode diagnosis dipengaruhi oleh ketepatan penulisan diagnosis, beban kerja coder, pengetahuan petugas rekam medis tentang bahasa terminologi medis, dan sarana (Depkes RI, 2010).

Menurut Khabibah (2013), didapatkan dalam penulisan diagnosis pada lembaran masuk dan keluar (CM 1) pada berkas rekam medis, ketidaktepatan penggunaan singkatan menurut terminologi sebesar $23(29,49 \%)$ dan ketidaktepatan penggunaan istilah sebesar $7(8,98 \%)$. Penulisan diagnosis dengan istilah terminologi medis yang tidak tepat menurut ICD-10 disebabkan karena belum adanya sosialisasi tentang keseragaman dalam penggunaan istilah dan singkatan dalam penulisan diagnosis dan belum dilakukannya pelatihan terhadap dokter atau petugas kesehatan yang bertugas dalam penulisan terminologi medis, sehingga banyak ditemukan diagnosis yang ditulis menggunakan campuran antara terminologi medis dengan bahasa Indonesia dan bahasa inggris. Hal ini akan berdampak pada saat petugas coding melakukan pengodean penyakit akan kesulitan untuk memahami dan menentukan lead term, sehingga diperlukan waktu yang lebih lama untuk mengubah istilah dalam bahasa Indonesia ke dalam istilah medis terlebih dahulu yang sesuai agar mempermudah dalam menentukan kode diagnosis. Namun apabila petugas coding tidak memahami terminologi medis akan mengalami kesulitan sehingga berdampak pada pemilihan kode diagnosis yang tepat.

Berdasarkan pengalaman Praktik Kerja Lapangan yang penulis lakukan di beberapa rumah sakit di dalam maupun di luar provinsi Bengkulu, seperti di Rumah Sakit Umum Daerah DR. M. Yunus Bengkulu, Rumah Sakit Rafflesia Bengkulu, 
dan Rumah Sakit Islam Klaten, didapatkan ketidaksesuaian penulisan terminologi medis pada CM 1 pasien rawat inap dan lembar poliklinik pasien rawat jalan Rumah Sakit Umum Daerah Dr. M. Yunus Bengkulu sebesar $60 \%$, Rumah Sakit Rafflesia Bengkulu sebesar 70 \%, dan Rumah Sakit Islam Klaten sebesar $60 \%$.

Rumah Sakit Umum Ummi Bengkulu baru berdiri sekitar 2 tahun sejak di terbitkannya SK Walikota tentang Izin Pendirian Rumah Sakit Umum Ummi Bengkulu nomor 153 tahun 2014. Rumah Sakit Umum Ummi Bengkulu adalah salah satu rumah sakit rujukan tipe $\mathrm{C}$ di kota Bengkulu, dengan layanan gawat darurat dan persalinan 24 jam. Rumah Sakit Umum Ummi Bengkulu memiliki 42 dokter yang melayani pasien rawat jalan, rawat inap maupun gawat darurat. Dengan petugas rekam medis sebanyak 14 orang dan hanya 1 orang yang berkualifikasi D3 rekam medis.

Penulis tertarik untuk melakukan penelitian di Rumah Sakit Umum Ummi Bengkulu karena Rumah Sakit Umum Ummi Bengkulu baru berdiri sekitar 2 tahun dan belum pernah dilakukan koreksi tentang kesesuaian penulisan terminologi medis pada CM 1 pasien rawat inap dan lembar poliklinik pasien rawat jalan.

Survei awal di Rumah Sakit Umum Ummi Bengkulu, bahwa dari sampel masing-masing 7 berkas rekam medis pasien rawat inap dan rawat jalan masih terdapat penulisan terminologi medis yang tidak sesuai dengan ICD-10 sebanyak 5 diagnosis. Hal ini disebabkan karena belum adanya sosialisasi kepada petugas kesehatan khususnya dokter tentang penulisan terminologi medis yang sesuai dengan ICD-10, belum dilakukan pelatihan terhadap dokter tentang penulisan terminologi medis yang harus sesuai dengan ICD-10, kurangnya pengawasan dan evaluasi terhadap terminologi medis yang tercantum pada CM 1 dan lembar poliklinik, belum adanya daftar singkatan yang ditetapkan sebagai acuan dalam penulisan terminologi medis, dan sudah adanya Standar Operasional Prosedur (SOP) tentang penulisan terminologi medis yang sesuai dengan ICD-10 sudah ada tetapi hanya terdapat di ruang rekam medis dan tidak terdapat di masing-masing ruang rawat pasien/ruang kerja dokter sehingga dokter yang menulis diagnosis tidak mengetahui Standar Operasional Prosedur (SOP) tentang penulisan terminologi medis yang sesuai dengan ICD-10 tersebut.

Penulisan terminologi medis yang tidak sesuai dengan ICD-10 akan berdampak pada saat petugas coding melakukan pengodean penyakit dan akan kesulitan untuk memahami diagnosis apa yang tercantum pada berkas rekam medis tersebut sehingga diperlukan waktu yang lebih lama untuk mengubah istilah dalam bahasa Indonesia ke dalam istilah medis terlebih dahulu yang sesuai agar mempermudah dalam menentukan kode diagnosis (Hatta, 2013). Permasalahan inilah yang mendorong peneliti tertarik untuk meneliti terkait penulisan terminologi medis pada CM 1 pasien rawat inap dan lembar poliklinik pasien rawat jalan di Rumah Sakit Umum Ummi Bengkulu periode januari-maret 2017.

\section{METODOLOGI PENELITIAN}

Penelitian ini merupakan penellititan deskriptif. Menurut Sastroasmoro dan Ismael dalam Oktavia (2017 : 14), penelitian deskriptif adalah penelitian yang bertujuan melakukan deskripsi mengenai fenomena yang ditemukan, baik yang berupa faktor risiko maupun efek atau hasil. Jenis penelitian yang digunakan dalam penelitian ini adalah metode penelitian deskriptif kuantitatif.

Populasi dalam penelitian ini adalah berkas rekam medis pasien rawat inap dan rawat jalan pada 
bulan januari-maret 2016 dengan jumlah 1.863 berkas rekam medis pasien rawat inap dan 3.725 berkas rekam medis pasien rawat jalan. Menurut Notoatmodjo dalam Oktavia (2017 : 19), populasi adalah sekelompok subyek atau data dengan karakteristik tertentu.

Teknik pengambilan sampel dalam penelitian ini adalah Systematic Random Sampling. Systematic Random Sampling yaitu membagi jumlah atau anggota populasi dengan perkiraan jumlah sampel yang diinginkan, hasilnya adalah interval sampel.

Menurut Riwidikdo dalam Oktavia (2017 : 31), variabel diartikan atribut dari subyek/obyek yang akan di teliti yang bervariasi antara satu subyek/obyek yang satu dengan yang lain. Variabel dalam penelitian ini adalah penulisan terminologi medis pada CM 1 pasien rawat inap dan lembar poliklinik pasien rawat jalan.

Instrumen dalam penelitian ini yaitu menggunakan alat bantu pengukuran berupa lembar checklist dan ICD-10 dan dilaksanakan pada tanggal 20 Juni-20 Juli 2017 di Rumah Sakit Umum Ummi Bengkulu.

\section{HASIL PENELITIAN}

Berdasarkan hasil penelitian terhadap 329 berkas rekam medis pasien rawat inap dan 361 berkas rekam medis pasien rawat jalan di Wilayah Kerja Rumah Sakit Umum Ummi Bengkulu, didapatkan penulisan terminologi medis pada CM 1 pasien rawat inap dan lembar poliklinik pasien rawat jalan menggunakan istilah dan singkatan yang sesuai dan tidak sesuai dengan ICD-10, dengan hasil sebagai berikut:

Tabel 4.1 Penulisan Terminologi Medis pada CM 1 Pasien Rawat Inap di Rumah Sakit Umum Ummi Bengkulu

\begin{tabular}{llcccccc}
\hline No & $\begin{array}{c}\text { Penulisan } \\
\text { Terminologi } \\
\text { Medis }\end{array}$ & $\begin{array}{c}\text { Sesuai } \\
\text { ICD-10 }\end{array}$ & $\begin{array}{c}\text { Tidak } \\
\text { Sesuai } \\
\text { ICD-10 }\end{array}$ & Jumlah \\
\cline { 2 - 8 } & & $\mathrm{n}$ & $\%$ & $\mathrm{n}$ & $\%$ & $\mathrm{n}$ & $\%$ \\
\hline 1 & $\begin{array}{l}\text { Menggunakan } \\
\text { istilah }\end{array}$ & 85 & 47 & 97 & 53 & 182 & 100 \\
\hline 2 & $\begin{array}{l}\text { Menggunakan } \\
\text { singkatan }\end{array}$ & 50 & 34 & 97 & 66 & 147 & 100 \\
\hline
\end{tabular}

Berdasarkan table 1 diatas menunjukkan dari 329 CM 1 pasien rawat inap didapatkan yaitu penulisan terminologi medis menggunakan istilah yang tidak sesuai dengan ICD-10 adalah sebesar 97 $(53 \%)$ dan penulisan terminologi medis menggunakan singkatan yang tidak sesuai dengan ICD-10 adalah sebesar 97 (66\%).

Tabel 2. Penulisan Terminologi Medis pada Lembar Poliklinik Pasien Rawat Jalan

di Rumah Sakit Umum Ummi Bengkulu

\begin{tabular}{|c|c|c|c|c|c|c|c|}
\hline \multirow[t]{2}{*}{ No } & \multirow{2}{*}{$\begin{array}{c}\text { Penulisan } \\
\text { Terminolog } \\
\text { i Medis }\end{array}$} & \multicolumn{2}{|c|}{$\begin{array}{c}\text { Sesuai } \\
\text { ICD-10 }\end{array}$} & \multicolumn{2}{|c|}{$\begin{array}{c}\text { Tidak } \\
\text { Sesuai } \\
\text { ICD-10 }\end{array}$} & \multicolumn{2}{|c|}{ Jumlah } \\
\hline & & $\mathrm{n}$ & $\%$ & $\mathrm{n}$ & $\%$ & $\mathrm{n}$ & $\%$ \\
\hline 1 & $\begin{array}{l}\text { Menggunak } \\
\text { an istilah }\end{array}$ & 50 & $\begin{array}{l}2 \\
4\end{array}$ & 161 & 76 & 211 & 100 \\
\hline \multirow[t]{2}{*}{2} & $\begin{array}{l}\text { Menggunak } \\
\text { an singkatan }\end{array}$ & 45 & $\begin{array}{l}3 \\
0\end{array}$ & 105 & 70 & 150 & 100 \\
\hline & & & & \multicolumn{2}{|c|}{ Jumlah } & 361 & 100 \\
\hline
\end{tabular}

Berdasarkan tabel 2 diatas menunjukkan dari 361 lembar poliklinik pada berkas rekam medis pasien rawat jalan didapatkan yaitu penulisan terminologi medis menggunakan istilah yang tidak sesuai dengan ICD-10 adalah sebesar 161 (76\%) dan penulisan terminologi medis yang menggunakan 
singkatan yang tidak sesuai dengan ICD-10 adalah sebesar $105(70 \%)$.

\section{PEMBAHASAN}

Berdasarkan tabel 4.1 tentang penulisan terminologi medis pada CM 1 pasien rawat inap di Rumah Sakit Umum Ummi Bengkulu periode januari-maret 2017 diketahui penulisan terminologi medis menggunakan istilah yang sesuai dengan ICD-10 yaitu sejumlah 85 terminologi medis (47\%), dan yang tidak sesuai dengan ICD-10 yaitu sejumlah 97 terminologi medis (53\%). Sedangkan penulisan terminologi medis menggunakan singkatan yang sesuai dengan ICD-10 yaitu sejumlah 50 terminologi medis (34\%), dan yang tidak sesuai dengan ICD-10 yaitu sejumlah 97 (66\%) dari 329 berkas rekam medis rawat inap.

Dalam kegiatan manajemen, faktor manusia paling menentukan. Titik pusat dari manajemen adalah manusia. Setiap kegiatan yang dilakukan sangat bergantung pada orang yang melakukannya (Rusdiarti, 2008). Berdasarkan Undang-Undang No. 36 Tahun 2009 tentang kesehatan, tenaga kesehatan adalah setiap orang yang mengabdikan diri dalam bidang kesehatan serta memiliki pengetahuan atau keterampilan melalui pendidikan di bidang kesehatan. Menurut Permenkes RI Nomor 269/MENKES/PER/III/2008, dokter, dokter gigi dan/atau tenaga kesehatan tertentu bertanggungjawab atas catatan dan/atau dokumen yang dibuat pada rekam medis.

Dokter yang merawat pasien mempunyai tugas dan tanggungjawab atas penegakan dan penulisan diagnosis sesuai dengan ICD-10. Oleh karenanya, diagnosis yang ditulis dalam rekam medis harus lengkap, tepat dan jelas sesuai dengan terminologi medis dan arahan yang ada pada buku ICD-10 (Hatta, 2013). Semua diagnosa dan prosedur harus dituliskan secara penuh, tanpa simbol, dengan istilah (terminologi) yang dapat diterima. (Huffman, 1999). Penulisan terminologi medis yang sesuai dengan ICD-10 tujuannya adalah untuk keseragaman bahasa, sehingga terminologi medis yang dituliskan dalam berkas rekam medis pasien dapat dibaca dan dimengerti serta untuk meningkatkan sarana komunikasi antar profesi kesehatan. Penggunaan lebih dari satu istilah untuk penyakit yang sama, menyulitkan dalam pengumpulan dan perolehan informasi morbiditas dan mortalitas yang akurat dan tepat (Hatta, 2013)

Berdasarkan hasil penelitian diketahui masih ada penulisan terminologi medis menggunakan istilah dan singkatan yang tidak sesuai dengan ICD10. Penulisan terminologi medis pada CM 1 pasien rawat inap yang tidak sesuai dengan ICD-10 yaitu banyak dilakukan oleh dokter spesialis penyakit dalam. Penulisan terminologi medis yang tidak sesuai dengan ICD-10, akan berdampak terhadap ketepatan kode diagnosis yang ditetapkan oleh seorang koder dan akan berpengaruh terhadap biaya pelayanan kesehatan. Hal ini sejalan dengan teori menurut Depkes RI (2010), yaitu apabila diagnosis dan kode yang dicantumkan pada berkas rekam medis tidak tepat, maka akan berdampak pada biaya pelayanan kesehatan.

Penyebab dari penulisan terminologi medis menggunakan istilah dan singkatan yang tidak sesuai dengan ICD-10 yaitu karena belum adanya sosialisasi tentang penulisan terminologi medis yang sesuai dengan ICD-10, belum dilakukan pelatihan terhadap dokter tentang penulisan terminologi medis yang harus sesuai dengan ICD-10, kurangnya pengawasan dan evaluasi terhadap terminologi medis yang tercantum pada CM 1 dan lembar poliklinik, belum adanya daftar singkatan yang ditetapkan sebagai acuan dalam penulisan terminologi medis dan sudah adanya Standar Operasional Prosedur (SOP) tentang penulisan terminologi medis yang sesuai dengan ICD-10 tetapi 
hanya terdapat di ruang rekam medis dan tidak terdapat di masing-masing ruang rawat pasien/ruang kerja dokter sehingga dokter yang menulis diagnosis tidak mengetahui Standar Operasional Prosedur (SOP) tentang penulisan terminologi medis yang sesuai dengan ICD-10 tersebut.

Rekam medis harus berisi informasi kesehatan yang ditulis secara konsisten, termasuk dalam penggunaan bahasa medis oleh dokter dan tenaga keperawatan maupun kebidanan yang pada akhirnya menjadi salah satu sarana komunikasi antar tenaga kesehatan, penunjang medis dan tenaga lain yang bekerja di bidang pelayanan kesehatan (Depkes, 2006).

Berdasarkan tabel 2 tentang penulisan terminologi medis pada lembar poliklinik pasien rawat jalan di Rumah Sakit Umum Ummi Bengkulu periode januari-maret 2017 diketahui penulisan terminologi medis menggunakan istilah yang sesuai dengan ICD-10 yaitu sejumlah 50 terminologi medis (24\%), dan yang tidak sesuai dengan ICD-10 yaitu sejumlah 161 terminologi medis (76\%). Sedangkan penulisan terminologi medis menggunakan singkatan yang sesuai dengan ICD-10 yaitu sejumlah 45 terminologi medis (30\%), dan yang tidak sesuai dengan ICD-10 yaitu sejumlah 105 (70\%) dari 361 berkas rekam medis rawat jalan.

Dalam kegiatan manajemen faktor manusia paling menentukan. Titik pusat dari manajemen adalah manusia. Setiap kegiatan yang dilakukan sangat bergantung pada orang yang melakukannya (Rusdiarti, 2008). Berdasarkan Undang-Undang No. 36 Tahun 2009 tentang kesehatan, tenaga kesehatan adalah setiap orang yang mengabdikan diri dalam bidang kesehatan serta memiliki pengetahuan atau keterampilan melalui pendidikan di bidang kesehatan. Menurut Permenkes RI Nomor 269/MENKES/PER/III/2008, dokter, dokter gigi dan/atau tenaga kesehatan tertentu bertanggungjawab atas catatan dan/atau dokumen yang dibuat pada rekam medis.

Dokter yang merawat pasien mempunyai tugas dan tanggungjawab atas penegakan dan penulisan diagnosis sesuai dengan ICD-10. Oleh karenanya, diagnosis yang ditulis dalam rekam medis harus lengkap, tepat dan jelas sesuai dengan terminologi medis dan arahan yang ada pada buku ICD-10 (Hatta, 2013). Semua diagnosa dan prosedur harus dituliskan secara penuh, tanpa simbol, dengan istilah (terminologi) yang dapat diterima. (Huffman, 1999). Penulisan terminologi medis yang sesuai dengan ICD-10 tujuannya adalah untuk keseragaman bahasa, sehingga terminologi medis yang dituliskan dalam berkas rekam medis pasien dapat dibaca dan dimengerti serta untuk meningkatkan sarana komunikasi antar profesi kesehatan. Penggunaan lebih dari satu istilah untuk penyakit yang sama, menyulitkan dalam pengumpulan dan perolehan informasi morbiditas dan mortalitas yang akurat dan tepat (Hatta, 2013).

Berdasarkan hasil penelitian diketahui masih ada penulisan terminologi medis menggunakan istilah dan singkatan yang tidak sesuai dengan ICD10. Penulisan terminologi medis pada CM 1 pasien rawat inap yang tidak sesuai dengan ICD-10 yaitu banyak dilakukan oleh dokter spesialis mata dan penyakit dalam.

Penyebab dari penulisan terminologi medis menggunakan istilah dan singkatan yang tidak sesuai dengan ICD-10 yaitu karena belum adanya sosialisasi tentang penulisan terminologi medis yang sesuai dengan ICD-10, belum dilakukan pelatihan terhadap dokter tentang penulisan terminologi medis yang harus sesuai dengan ICD-10, kurangnya pengawasan dan evaluasi terhadap terminologi medis yang tercantum pada CM 1 dan lembar poliklinik, belum adanya daftar singkatan yang ditetapkan sebagai acuan dalam penulisan terminologi medis dan sudah adanya Standar 
Operasional Prosedur (SOP) tentang penulisan terminologi medis yang sesuai dengan ICD-10 tetapi hanya terdapat di ruang rekam medis dan tidak terdapat di masing-masing ruang rawat pasien/ruang kerja dokter sehingga dokter yang menulis diagnosis tidak mengetahui Standar Operasional Prosedur (SOP) tentang penulisan terminologi medis yang sesuai dengan ICD-10 tersebut.

Menurut Depkes (2006), bahwa penetapan diagnosis seorang pasien merupakan kewajiban, hak dan tanggungjawab dokter (tenaga medis) terkait. Dokter sebagai penentu perawatan harus memilih kondisi utama dan kondisi lain dalam periode perawatan. Tenaga perekam medis sebagai pemberi kode bertanggung jawab atas keakuratan kode dari suatu diagnosis yang telah ditetapkan oleh tenaga medis, sebelum memberikan kode penyakit tenaga medis harus mengkaji data rekam medis pasien untuk menemukan hal yang kurang jelas atau tidak lengkap.

\section{KESIMPULAN}

Dari hasil penelitian dan pembahasan Karya Tulis Ilmiah, maka dapat disimpulkan:

1. Diketahui dari $329 \mathrm{CM} 1$ pasien rawat inap didapatkan penulisan terminologi medis menggunakan istilah yang tidak sesuai dengan ICD-10 adalah 97 (53\%) dan penulisan terminologi medis menggunakan singkatan yang tidak sesuai dengan ICD-10 adalah 97 $(66 \%)$.

2. Diketahui dari 361 lembar poliklinik pasien rawat jalan didapatkan penulisan terminologi medis menggunakan istilah yang tidak sesuai dengan ICD-10 adalah 161 (76\%) dan penulisan terminologi medis yang menggunakan singkatan yang tidak sesuai dengan ICD-10 adalah 105 (70\%).
Diharapkan di masa yang akan datang dapat digunakan sebagai salah satu sumber data dari peneliti yang akan melakukan penelitian selanjutnya dan dilakukan penelitian lebih lanjut berdasarkan faktor lainnya, variabel yang berbeda, jumlah sampel yang lebih banyak, tempat yang berbeda, dan tetap berhubungan dengan penulisan terminologi medis.

\section{DAFTAR PUSTAKA}

Chusnawati. (2013). Tinjauan Kesesuaian Penggunaan Terminologi Medis pada Penulisan Diagnosis di Medical Center UNS Bulan Februari 2013. Jurnal Rekam Medis 7 (1): 13-20.

Depkes RI. (2006). Pedoman Penyelenggaraan dan Prosedur Rekam Medis Rumah Sakit Indonesia. Jakarta: Direktorat Jendral Pelayanan Medik.

(2010). Pedoman Penyelenggaraan dan Prosedur Rekam Medis Rumah Sakit Indonesia. Jakarta: Direktorat Jendral Pelayanan Medik.

Hatta. R. G. (2013). Pedoman Manajemen Informasi Kesehatan disarana Pelayanan Kesehatan. Jakarta: Universitas Indonesia.

Huffman, K. E. (1999). Health Information Management. Padang: Apikes Dharma Lanbaw.

Khabibah. (2013). Tinjauan Ketepatan Terminologi Medis dalam Penulisan Diagnosis pada Lembaran Masuk dan Keluar di RSU Jati Husada Karanganyar. Jurnal Manajemen Informasi Kesehatan Indonesia 1 (2): 46-52.

Medical Abbreviations Glossary. (2009), (diakses 16 Mei 2017), diunduh www. jdmd. com.

Notoatmodjo, S. (2015). Pengembangan Sumber Daya Manusia. Jakarta: Rineka Cipta.

Nuryati. (2011). Terminologi Medis Pengenalan Istilah Medis. Bantul: Quantum Sinergis Media.

Oktavia, N. (2017). Buku Pedoman Penulisan Karya Tulis Ilmiah Diploma III Tahun 2017. Bengkulu: BeGe Percetakan.

Permenkes RI Nomor 269/MENKES/PER/III/2008 tentang rekam medis. 
Rusdiarti, K. (2008). Ekonomi: Fenomena di Sekitar Kita 3. Jawa Tengah: Platinum.

Undang-Undang Nomor 29 tahun 2004 Tentang Praktik Kedokteran.

Undang-Undang No. 36 tahun 2009 Tentang Kesehatan.

WHO. (2010). Health Topics, (diakses 20 Mei 2017), diunduh dari http://www.who.int.org 